\title{
ŚWIATŁO ZE WSCHODU. O ESEJACH NIE CAEKIEM POLSKICH TOKIMASY SEKIGUCHIEGO
}

W ostatnich latach Cross- i Trans-cultural studies rozwijają się bardzo dynamicznie. Liczący się wkład w tę dziedzinę badań mają badacze japońscy, w tym uczeni z Tokijskiego Uniwersytetu Spraw Międzynarodowych (Tōkyō Gaikokugo Daigaku, ang. Tokyo University of Foreign Studies, dalej: TUFS). Na tym uniwersytecie działa Instytut Studiów Transkulturowych, który publikuje rocznik „Trans-cultural Studies” (t. 1-20, 1997-2016). Jednym z autorów ważnych na tym obszarze badawczym jest Tokimasa Sekiguchi, wybitny polonista, emerytowany profesor tej uczelni, którego książka pt. Eseje nie całkiem polskie ukazała się w języku polskim, w Krakowie ${ }^{1}$ - w perspektywie transkulturowej miejsce wydania książki można określić mianem polskiego Kyoto. Zarówno Cross-cultural, jak i Trans-cultural studies mogą być uprawiane jako dyscypliny teoretyczne, których przedmiotem jest analiza procesu uwarunkowań wzajemnej infiltracji kultur. Można je uprawiać także nieco inaczej, jak czyni to m.in. Tokimasa Sekiguchi. Rzadko wypowiada się on w sprawach czysto teoretycznych. W swoich pracach natomiast dokonuje wnikliwej analizy drugiej kultury, w przypadku omawianej książki kultury polskiej, ukazując ją z perspektywy Japończyka. Chociaż sam autor zastrzega, że jego eseje sa „nie całkiem polskie”, to są one - zwłaszcza w pierwszej części książki - polskie na wskroś. Ich autor bowiem patrzy na sprawy polskie nie tylko z pozycji zewnętrznego obserwatora, lecz również niejako od wewnątrz. Ta druga perspektywa, jak sądzę, niejednokrotnie dominuje. Jest bowiem Tokimasa Sekiguchi nie tylko uczonym, badaczem, który do przedmiotu swoich badań podchodzi sine ira et studio, lecz także człowiekiem głęboko zanurzonym w kilku kulturach - najpierw w japońskiej, jego ojczystej, o której wypowiada się ze znawstwem, a przede wszystkim z wielką miłościa; następnie w polskiej, którą zna jakby to była

1 T. Sekiguchi, Eseje nie całkiem polskie, Universitas, Kraków 2016, ss. 278. Cytaty z tej książki lokalizuję, podając w tekście numer strony w nawiasach. Na okładce i stronie tytułowej książki wydawca wskazuje autora książki zgodnie z polskim zwyczajem językowym, to znaczy najpierw imię, później nazwisko. W tym artykule trzymam się tej konwencji. Ze względów stylistycznych czasami używam japońskich tytułów san $(\approx$ pan $)$ i sensei $(\approx$ mistrz, nauczyciel). Stawia się je po nazwisku. Natomiast w swojej książce autor konsekwentnie stosuje zwyczaj japoński (nazwisko plus imię). 
kultura jego własna; wreszcie - co wiem z bezpośrednich kontaktów - nieobca mu jest kultura innych krajów europejskich, francuska, którą zna najlepiej ze względu na swoje studia, a także kultura chińska i koreańska, którym poświęca sporo uwagi zwłaszcza w ostatnich latach, również w związku z cyklem konferencji Spotkania polonistyk trzech krajów: Chiny - Japonia - Korea, który zapoczątkował². Tokimasa Sekiguchi - wróćmy po tej dygresji do autora Esejów nie catkiem polskich - jest osobą perfekcyjnie bilingwalna. Omawiana książka nie jest przekładem - eseje zostały napisane po polsku i stanowia przykład stylistycznego i kompozycyjnego mistrzostwa, jakby to był dla ich autora język ojczysty, chciałoby się nawet powiedzieć, wykorzystując rzadziej w języku polskim używany idiom, jego ,język serca”. Profesor Sekiguchi jest także osobą całkowicie dwukulturowa (bicultural, 二文化), co pozwala mu swobodnie poruszać się po dwóch kulturach i językach. O jego dorobku w Japonii i w języku japońskim nie mogę się wypowiadać, nie znając tego języka. Powiem więc tylko, że jest on znany jako profesor polonistyki Tokijskiego Uniwersytetu Spraw Międzynarodowych $^{3}$, jako tłumacz literatury polskiej na język japoński (m.in. przekładał dzieła klasyków literatury polskiej, takie jak Treny Kochanowskiego ${ }^{4}$, Ballady i romanse Mickiewi$\mathrm{cza}^{5}$, dramaty Witkiewicza ${ }^{6}$, Iwone, księ̇nic zke Burgunda Gombrowicza ${ }^{7}$, opowiadania

2 Spotkania polonistów z Azji Wschodniej (Chiny, Japonia, Korea) rozpoczęły się w październiku 2007 r. w Seulu (Korea Południowa), gdy z okazji dwudziestolecia polonistyki na Uniwersytecie Języków Obcych HUFS zorganizowano konferencję nt. Studia polonistyczne w Azji. W kolejnych latach, już pod nazwą Spotkania polonistyk trzech krajów: Chiny - Japonia - Korea, poloniści z tych krajów oraz ich polscy współpracownicy spotykali się w Chinach, Japonii i Korei. Paradoksalnie, choć są to spotkania nauczycieli języka i kultury polskiej w tych krajach oraz badaczy kultury polskiej pracujących w trzech uniwersytetach, będących naprzemiennie organizatorami konferencji - Pekińskim Uniwersytecie Języków Obcych (Běijīng Wàiguóyǔ Dàxué, Pekin, Chiny - uczelnia znana w świecie pod angielską nazwą Beijing Foreign Studies University), Uniwersytecie Języków Obcych HUFS (Seul, Korea - powszechnie znany jako Hankuk University of Foreign Studies) oraz TUFS (Japonia), to jest to także konfrontacja kultur chińskiej, japońskiej i koreańskiej. Zob. B. Morcinek, Spotkania polonistyk trzech krajów: Chiny - Korea - Japonia, „Postscriptum Polonistyczne” 2010, nr 2 (6), s. 261-267. Ostatnie, piąte Spotkania, odbyły się na Kantońskim Uniwersytecie Spraw Międzynarodowych (GDUFS) w listopadzie 2016 r. w Kantonie (Guangzhou). Materiały z konferencji w 2007 r. ukazały się w tomie pt. Studia polonistyczne w Ažji (Seoul 2007). Od kolejnej konferencji zaczęto publikować rocznik pt. „Spotkania Polonistyk Trzech Krajów”. Ukazało się pięć tomów. Z żalem stwierdzam, że krajowe biblioteki naukowe, nawet Biblioteka Narodowa w Warszawie, nie mają kompletu tych wydawnictw.

3 O polonistyce w Japonii zob. T. Splisgart, Studia polonistyczne w Japonii. Historia orazperspektyny rozwoju, „Gdańskie Studia Azji Wschodniej” 2013, z. 3, s. 112-122.

4. Kohanofusuki, Banka, przeł. T. Sekiguchi, Tōkyō 2013.

A. Mitsukiēvichi, Barädo to romansu, przeł. T. Sekiguchi, Tōkyō 2014.

6 S.I. Vitokyēvichi, Vitokatsi no gikyoku yonpen, Tōkyō 2015. Tom zawiera następujące dramaty Witkacego: W matym dworku, Kurka wodna, Wariat i zakonnica, Matka.

7 Przekład ukazał się w 5 tomie serii Klasyka Literatury Polskiej (Pōrando Bungaku Koten Sösho), zawierającej dramat Szymona Anskiego Dybuk oraz właśnie Iwone, księznicæłke Burgunda 
Iwaszkiewicza ${ }^{8}$, Lalke Prusa ${ }^{9}$ a także listy Chopina ${ }^{10}$ i ważną dla poznania kultury polskiej Historie literatury polskiej Czesława Miłosza ${ }^{11}$ ), wreszcie jako uczony, który patrzy na Polskę i Europę w perspektywie cross- czy transkulturowej ${ }^{12}$, a nie są to wszystkie dziedziny jego naukowej i organizacyjnej aktywności. W tym artykule natomiast zamierzam jedynie przedstawić książkę Eseje nie catkiem polskie, która została podzielona na trzy części.

W pierwszej części książki zebrano eseje historycznoliterackie. Sekiguchi Sensei daje się tu poznać jako bardzo wnikliwy czytelnik współczesnej liryki polskiej (Herberta, Szymborskiej, Miłosza). Źródłem tej wnikliwości jest perspektywa translatorska. Autor esejów albo sam tłumaczy(ł) omawiane przez siebie teksty literackie, albo czyta je tak jak tłumacz. Choć, o czym już była mowa, posługuje się polszczyzną tak, jakby język polski był jego pierwszym językiem, nie jest - mówiąc jego słowami - „odbiorca polskojęzycznym wychowanym w Polsce” (s. 23). To sprawia, że nie daje się zwieść, jak to się niekiedy zdarza native speakerom, pozornej zrozumiałości języka i dostrzega to, czego my, zanurzeni w polszczyźnie i we własnej kulturze, nie chcemy bądź nie możemy dostrzec. W eseju Hirobito dla Zbigniewa Herberta (s. 7-22) Sekiguchi czyta mniej znany, pomijany w antologiach ${ }^{13}$, wiersz Herberta $W^{\prime} z_{z}$ z tomu Elegia na odejście i cierpliwie wyjaśnia odbiorcy polskiemu japońskie realia. Pisze m.in. o dorocznej ceremonii uta-kai-hajime, o roli „króla japońskiego” i rodziny królewskiej w tym wydarzeniu, o gatunkach literackich tanka i haiku, etc. Natomiast dosyć ogólnie, by nie powiedzieć zdawkowo, informuje o źródłach inspiracji Herberta, pisząc: „Herbert miał do dyspozycji wszystkie 45 utworów w przekładzie angielskim lub francuskim” (mowa o noworocznych tankach z 1988 r., s. 13); „musiał

Gombrowicza. Zob. S. An-Suki, Dibukku, przeł. M. Akao, V. Gonburōvichi, Burugunto kōjo Ivona, red. M. Nishi, Tōkyō 2015.

8 Ibashukiebitchi, Nisō Yoanna, przeł. T. Sekiguchi, Tōkyō 1997.

9 Japoński przekład Lalki ukazał się w Tokio nakładem wydawnictwa Publisher Michitani. Oficjalna data wydania 30 listopada $2017 \mathrm{r}$.

10 Z. Helman, Z. Skowron, H. Wróblewska-Straus, Shopan zenshokan 1816-1831 nen-Pōrando Jidai, przeł. T. Sekiguchi, M. Shigekawa, R. Hiraiwa, S. Nishida, Tokio 2011. O tym przekładzie T. Sekiguchi pisze w eseju pt. Refleksje ttumacza nowej Korespondencji Fryderyka Chopina (2009) [w:] idem, Eseje..., s. 253-266.

${ }^{11}$ Ch. Miuoshu, Pōrando bungakushi, przeł. T. Sekiguchi, Tōkyō 2006. O tym, dlaczego autor Esejón nie całkiem polskich wybrał właśnie Historie literatury polskiej Czesława Miłosza, a nie np. Juliana Krzyżanowskiego, zob. T. Sekiguchi, Teksty polskie w kontekstach pozapolskich [w:] idem, Eseje..., s. 153-154. T. Sekiguchi jest także współredaktorem wyboru wierszy Miłosza w języku japońskim, por. Ch. Miuoshu, Chesuwafu Minoshu shishū, przeł. H. Ogura, red. T. Sekiguchi, M. Numano, Yokohama 2011.

12 Myślę tu np. o jego japońskiej książce Polska i inni - kultura, retoryka, mapy z 2014 r., zob. T. Sekiguchi, Pōrando to tasha: bunka-retorikku-chįu, Tōkyō 2014.

13 Jak podaje Sekiguchi (s. 9), utwór nie wszedł np. do Wierşy wybranych Herberta z 2007 r. (oprac. R. Krynicki, Kraków 2007). 
dysponować bardzo dobrymi przekładami” (s. 17); „obejrzał w Paryżu jakiś film dokumentalny czy też audycję telewizyjną" (s. 20). Dzięki temu esej zyskuje na wartości, gdyż nieistotne i niepotrzebne dla zrozumienia utworu szczegóły nie zaprzątają uwagi czytelnika. Chociaż Herbert poznał obecne w utworze japońskie realia pośrednio, badacz kilka razy z uznaniem wypowiada się na temat wiedzy poety, np. na s. 16 czytamy: „poziom jego wiedzy na temat owego Tennō, czyli japońskiego króla, w chwili tworzenia omawianego wiersza o niebo przewyższał poziom ogółu publiczności polskiej”, a na s. 19: „Zbigniew Herbert dotarł do głębi tanki Hirohita”. Dlatego w ostatecznej konkluzji badacz może napisać, że uznaje „Wóz za wzorowy utwór, w którym zaowocowało owo »kultywowanie zanikającej umiejętności kontemplacji« poety. Tyle że dokonało się to nie wewnątrz literatury polskojęzycznej, lecz w obszarach już wybitnie transkulturowych tekstów literatury światowej” (s. 21). Wywód badacza zakończony tą konkluzją uwiarygodnia oświadczenie badacza z początku artykułu: „wiersz dotknął rzeczywistości japońskiej” (s. 11). Czy spełni się oczekiwanie Sekiguchiego, by Wóz Herberta mógł „z powrotem odnaleźć dla siebie miejsce, mocniej - powiedzmy - zaistnieć w przestrzeni polskojęzycznej i tym samym dotknąć ostatecznie polskiej rzeczywistości na zasadzie niejako sprzężenia zwrotnego" (s. 11), pokaże czas.

Nawet niezbyt uważny czytelnik dostrzeże, że w tym eseju Sekiguchi konsekwentnie nazywa władcę Japonii „królem”. U Herberta stereotypowy cesarz jest skonfrontowany z realnym władca: „,...) im bardziej anachroniczny jest w ten sposób przygotowany obraz Hirohita, tym efektowniej wypada ujawnienie w dalszej części tego tekstu jego realnej postaci jako poety-humanisty" (s. 16). Sam badacz chce jednak uniknąć tych stereotypów w swoim eseju. Dlatego przekroczenie polskiego zwyczaju językowego uznaję za uzasadnione. To dowód wielkiej świadomości językowej autora eseju.

W eseju Radykalność i otwartość liryki Wistany Sazymborskiej - lektura heterodoksyjna (s. 23-58) Sekiguchi czyta wiersze noblistki z Krakowa. Jak zaznacza już w tytule, jest to lektura nieortodoksyjna, a przynajmniej „taka może się wydawać (...) odbiorcom polskojęzycznym wychowanym w Polsce" (s. 23). W ujęciu eseisty poezja Szymborskiej jest zarówno radykalna, co u niego znaczy sięgająca do głębi, do korzeni (łac. radix), jak i otwarta, a tylko takie teksty mogą wejść do literatury światowej. Jeśli o poezji Szymborskiej można powiedzieć, że jest otwarta, to tym samym o eseju Sekiguchiego, że otwiera poezję autorki Chwili na nowe odczytania.

Gdy czytałem esej Radykalność i otwartość liryki Wistany Szymborskiej, cały czas prześladowało mnie słowo „intertekstualność”, jeśli w tym kontekście można jeszcze mówić o intertekstualności. Jak autor pisze o swoim czytaniu Szymborskiej, „w momencie lektury oryginalnego tekstu polskiego (...) łączy się on we mnie naturalnie z innymi różnorodnymi tekstami, wśród których, wydaje się, dominują - o dziwo! - teksty japońskie, a nie polskie" (s. 39). Ta łączność, wspólna przestrzeń tekstowa nie wynika, a przynajmniej Sekiguchi o tym nawet nie napomyka, 
z wpływu japońskich tekstów literackich, religijnych czy filozoficznych na Szymborska. Skądinąd, biorąc pod uwagę zdumiewające paralele między tekstami polskiej noblistki a tekstami zen, pytanie o inspirację nie musi wydawać się niedorzeczne, choćby dlatego, że buddyzm w różnych odmianach był w Polsce znany od schyłku XIX w. Nie znając bliżej twórczości Szymborskiej, przypominam sobie naprędce słowo Budda (według Sekiguchiego - kultowa ikona) w jej wierszu Pokój samobójcy z tomu Wielka lič̨̧a: „Budda niefrasobliwy, Jezus frasobliwy” ${ }^{14}$. Jeśli autor eseju nie stawia pytania o źródła tych dostrzegalnych paraleli, to dlatego, że traktuje je jako rezultat tej samej wrażliwości, myślenia przyrodniczego, braku dogmatycznego dedukcjonizmu religijnego lub filozoficznego (s. 52). Przykłady podane w eseju zdaja się mówić, że postawa Szymborskiej jest zbyt radykalna (w sensie, w jakim używa tego przymiotnika Sekiguchi), by szukanie inspiracji było potrzebne.

W związku z tym tekstem jeszcze dwa drobiazgi. Cały czas podziwiam intuicję językową autora. W eseju o poezji Szymborskiej jednak Sekiguchi sensei daje się zwieść polszczyźnie. Pisząc o żywotności idei reinkarnacji w Japonii, dodaje na marginesie: „Zresztą i w Polsce ciagle popularne są zwroty w rodzaju: »w poprzednim wcieleniu«, ॥w następnym wcieleniu«..." (s. 41). Moja intuicja podpowiada mi, że nie można o tych zwrotach (technicznie rzecz ujmując, są to wyrażenia) powiedzieć, iż są ciagle popularne, gdyż są raczej nowe. Dowodzi tego ich nieobecność w dawniejszych słownikach, np. nie zostały odnotowane w Stowniku frazeologicznym jezyka polskiego Stanisława Skorupki ${ }^{15}$. Szybka i doraźna kwerenda w zasobach sieciowych (Google Books) pokazuje, że mogę mieć rację - nie znajdujemy tych wyrażeń w tekstach dziewiętnastowiecznych, natomiast w XX w. ich obecność nasila się w ostatnim ćwierćwieczu, przy czym dominują tu teksty religioznawcze. Obecnie rzeczywiście są to wyrażenia już obiegowe. Intuicja nie zawodzi jednak autora, gdy, pisząc o atmanie, dodaje: „wieczne Ja-Dusza, mówiąc po polsku" (s. 29). Przynajmniej od czasu moich studiów intryguje mnie pytanie, kim jest to ja, które ma duszę (por. taki ciąg sensownych polskich zdań: Mam samochód. Mam żone i dzৃieci. Mam głowe. Wreszcie: Mam dusz̨e) Myślę, że w ten sam sposób mówi się o duszy nie tylko po polsku. Przykładem może być chociażby, błędnie przypisywane C.S. Lewisowi, powiedzenie: „You don't have a soul, Doctor. You are a soul. You have a body, temporarily" ${ }^{\prime 16}$.

W utworze Miejsce urodzenia i miejsce śmierci poety - problem zwany Czestawem Mitoszem (s. 59-75) eseista przez sześć dni wędruje z Krakowa na Litwę, „aby móc zmierzyć i przeżyć dystans, jaki istniał, powiedzmy sto lat temu, między Doliną Issy a Wawelem" (s. 75). Nie jest to jednak zapis wrażeń z tej naukowej peregry-

\footnotetext{
14 W. Szymborska, Wielka liçba, Warszawa 1976, s. 34.

15 Hasło: Wielenie [w:] S. Skorupka, Stownik frazeologiczny jesylka polskiego, wyd. 6, t. 2, Warszawa 1989, s. 520.

16 W.M. Miller Jr., A Canticle for Leibowitr, New York 1959, s. 272.
} 
nacji po miejscach ważnych dla polskiej kultury, lecz naukowa refleksja nad życiem i twórczością Czesława Miłosza. Miejsce urodzin polskiego noblisty staje się pretekstem do przedstawienia krętych ścieżek naukowego poznania, w tym wypadku chodzi o pojęcie Litwy. Nam, „odbiorcom polskojęzycznym wychowanym w Polsce", wydają się one oczywiste, przyjmujemy je z dobrodziejstwem inwentarza. Czy słusznie? „Jest rzeczą niezrozumiała, że człowiek - pisze o sobie Sekiguchi - który wcześniej przez co najmniej dziesięć lat, czytając teksty polonistyczne czy historyczne, miał do czynienia ze słowem »Litwa«, jak gdyby odkrył je na nowo albo dopiero sobie uświadomił jego istnienie" (s. 60). Autor esejów odkrył na nowo pojęcie Litwa dzięki lekturze Ziemi jatowej Thomasa S. Eliota, a „Owa świeżość pojęcia Litwy była może spowodowana tym, że przyszło ono niespodziewanie z innego kierunku, w innym świetle" (s. 60). Wędrując po ważnych dla twórczości Miłosza miejscach, eseista próbuje odpowiedzieć sobie na pytanie, co nie pozwala mu wzruszać się poetyckimi opisami Miłoszowego litewskiego świata, skąd bierze się w nim opór wobec tekstów autora Doliny Issy. Jego źródłem jest retoryka poety - Sekiguchi „,wyczuwa więcej mistyfikacji niż inkarnacji w Miłoszowskiej poezji litewskiej” (s. 67). Myślę, że to poważne oskarżenie wobec twórczości, tym ważniejsze że przyszło niespodziewanie z innego kierunku i przedstawia tę twórczość w innym świetle.

Natomiast Kraków, miejsce śmierci poety, staje się dla eseisty punktem wyjścia do przypomnienia, jak „myślenie po polsku nadal jest mocno uwarunkowane romantyzmem" (s. 60). Pretekstem do tego przypomnienia stał się spór o miejsce pochówku Czesława Miłosza. Myślę, że nie będzie przesada, jeśli podkreślę tu doskonała orientację autora omawianej książki w sprawach polskich, znajomość realiów i środowisk, doraźnej publicystyki. Zdaniem Sekiguchiego „całokształt wrzawy i widowiska powstałych wokół pochówku Miłosza na Skałce wskazuje na silne przetrwanie w przestrzeni polskojęzycznej jednego a powszechnego systemu wartości, jaki można po angielsku określić bez skrupułów mianem nationalism” (s. 71), a obie strony konfliktu, dziś zresztą już zupełnie wygasłego, ,sa zgodne co do znaczenia i wagi samego aktu pochówku na Skałce. Dla wszystkich ma on znaczenie i funkcję” (s. 71). Trudno o trafniejszą diagnozę. Postawił ją nie tyle „postronny obserwator" (s. 71), ile obserwator bezstronny, a nawet życzliwy, niemniej z wyraźnie ukształtowanym systemem wartości i światopoglądem. Tu i w innych miejscach książki Tokimasa Sekiguchi staje w opozycji nie do Polaków i ich kultury, ale do nacjonalizmu. W jednym nie bardzo chciałbym się jednak z autorem zgodzić. Należę raczej do tych, którzy ten „jeden a powszechny system wartości” - jak autor eseju nazywa nacjonalizm - postrzegają nie jako zło absolutne, lecz uznają narody za rodzaj historycznie ukształtowanych zbiorowych tożsamości. Większą ufność pokładam w istniejących i w jakimś stopniu sprawdzonych formach organizacji życia społecznego niż w społecznej inżynierii. Sądzę, że problem nie leży w tym, że polska tożsamość tu i teraz ma albo jeszcze przechowuje narodowy charakter. Idzie raczej o proporcje, o nadmierne i niczym nieuzasadnione poczucie wyższości, o (nie 
tylko polska) megalomanię ${ }^{17}$. Powiedziałbym nationalism ${ }^{18}$ tak, chauvinisme (skrajna postać nacjonalizmu, excessive or blind patriotism) nie.

O Czesławie Miłoszu Tokimasa Sekiguchi wypowiada się jeszcze raz w eseju Forsycja i czeremcha (s. 221-235). Oceniając Miłoszowe przekłady japońskich wierszy haiku, badacz pisze: „Biorąc pod uwage autorytet poety, muszę użyć ostrego wyrażenia, że to wręcz karygodne taką parodię, i to nieudaną, opublikować pod imieniem Bashō” (s. 230). Przytaczam tę opinię, gdyż pojawia się przy okazji rozważania innych zagadnień i mogłaby ujść uwadze czytelnika. Nie zmienia to oczywiście wagi osądu przekładów Miłosza z języka japońskiego.

Zanim przejdę do omówienia kolejnych esejów i części książki, jeszcze jedna watpliwość, już zupełnie innego rodzaju. W Ziemi jałowej T.S. Eliota autor esejów widzi „poemat o cywilizacji indoeuropejskiej” (s. 63). Nie znam tak dobrze cyklu Eliota, by kwestionować tę opinię. Moją uwagę zwrócił sam termin „cywilizacja indoeuropejska". Czy o cywilizacji indoeuropejskiej nie da się powiedzieć tego, co w innym miejscu Tokimasa Sekiguchi mówi o Azji - że to galimafrée (s. 163) kultur, religii i ludów? Wszystkie te ludy mówią językami wywodzącymi się ze wspólnego prajęzyka, przechowały z odległej przeszłości niektóre wątki mitologiczne ${ }^{19}$, czasem odnajdujemy w Europie kulturowe artefakty świadczące o wspólnocie kulturoweje ${ }^{20}$, ale trudno używać pojęcia cywilizacja indoeuropejska w takim sensie, w jakim mówimy np. o cywilizacji chrześcijańskiej.

Trzy eseje poświęcone są prozie - dawnej (Sienkiewicz, Prus) oraz współczesnej (Gombrowicz). Zamyka tę część zbioru esej o charakterze ogólnym pt. Teksty polskie w kontekstach pozapolonistycznych (s. 141-154). Esej o Sienkiewiczu (Z Panem Wołodyjowskim do Kamieñca - inne spojrzenenie na Trylogię Henryka Sienkiewicza, s. 77-98) przedstawiam dalej, w omówieniu drugiej części Esejów nie całkiem polskich. Chociaż dotyczy on problematyki ściśle literackiej (hermetyczne zamknięcie się literatury polskiej od romantyzmu, Kresy w kulturze polskiej etc.), to jest równocześnie interesująca i ważna praca z zakresu krytyki postkolonialnej i dobrze komponuje się $\mathrm{z}$ esejem Arja nie istrieje.

17 Megalomania narodowa nie jest zjawiskiem specyficznie polskim. Por. J.S. Bystroń, Megalomania narodowa. Źródta - teorie - skutki, „Przegląd Współczesny” 1923, R. II, t. 7, s. 371-396.

18 Tak jak T. Sekiguchi uciekam się tu do rzeczownika angielskiego, choć chyba z nieco innego powodu. Moim zdaniem w niektórych sytuacjach nationalism w angielskim (amerykańskim) może być synonimem patriotyzmu (por. np. American nationalism is often most visible during Fourth of July celebrations, https://www.merriam-webster.com/thesaurus/nationalism (dostęp: 11.08.2017). Wspó1czesny polski zwyczaj językowy na tego typu użycia rzeczownika „nacjonalizm” nie pozwala.

19 Odkrywczą dla mnie książkę na ten temat opublikowal niedawno Dariusz Seweryn (Prehistoria, średniowiecze, romantyzm. W kregu indoeuropejskich tematów mitologicznych. Od Dumézila do Stowackiego, Warszawa 2014).

20 Ciekawym przykładem mogą być dzieje bandury, instrumentu postrzeganego jako typowo ukraiński. Jak pisze Irina Zinkiw, ukraińska bandura wywodzi się z Indii i dowodzi dawnej wspólnoty kulturowej (eadem, Bandura jak istorycznyj instrument, Kyjiw 2013). 
W tekście pt. Bolestaw Prus o Japonii i Japońçy)kach (s. 121-154) poznajemy utwory publicystyczne Prusa o Kraju Wschodzącego Słońca i jego mieszkańcach (wzmianki w Kronikach, cykl Japonia i Japońcsyyy z okresu wojny rosyjsko-japońskiej). Analiza tych tekstów - dość nieuchronnie - prowadzi Sekiguchiego do konkluzji, „że stereotypowa Japonia w świadomości późniejszych Polaków odnajduje tu swój piękny archetyp” (s. 133). W Kronikach Prus dydaktyk, „prawdziwy pozytywista warszawski z fin-de-siècle'u' (s. 126) wykorzystuje Japonię instrumentalnie, by na tym tle powiedzieć coś o ówczesnej Polsce i społeczeństwie polskim. Natomiast studium Japonia i Japońcsycy ocenia negatywnie - niska merytorycznie jakość przy pozornej erudycji autora (s. 136). Eseista przypomina też, że w tym samym czasie „w ówczesnej Polsce nie brakowało ludzi, którzy dzięki swoim dogłębnym dociekaniom potrafili spojrzeć na Japonię inaczej niż ogół” (s. 136), np. Feliks Manggha-Jasieński, Jan August Kisielewski, Miriam-Przesmycki. W ostatecznym rozrachunku „w tym, co pisał Prus (...) odnajdujemy niewiele prawdy o Japonii. Za to mamy tu znakomite materiały do poznania stanu wiedzy ówczesnych Polaków o świecie, ich wyobrażeń o sobie i innych" (s. 141). Tokimasa Sekiguchi 20 lat temu wyraził nadzieję, że tą problematyką zajmie się prusolog z prawdziwego zdarzenia (s. 142). Nie wydaje mi się, by tak się stało. Sądzę jednak, że takimi badaniami z uwzględnieniem perspektywy krytyki postkolonialnej należy objąć twórczość innych pisarzy oraz odnoszącą się do innych krajów i części świata. Jak pokazał eseista, w ten sposób możemy lepiej poznać przede wszystkich samych siebie.

Recepcję Gombrowicza w Japonii Tokimasa Sekiguchi przedstawia w eseju Gombrowicz, caytany pionowo (s. 99-119). Jak dowiadujemy się z pierwszego akapitu, esej ma charakter „szkicu faktograficznego”. Sekiguchi omawia kolejno znajomość Gombrowicza przez dwu wybitnych pisarzy japońskich - Yukio Mishimę (1925-1970) i Masahiko Shimadę (ur. 1961) - oraz krytyka literackiego, badacza kultury i literatury porównawczej, polonistę i eseistę Masahiko Nishiego (ur. 1955). Nie zajmuje się natomiast tłumaczeniami i wydaniami Gombrowicza w Japonii. Daje jedynie ich zestawienie w aneksie pt. Gombrowicz w Japonii - lista prz̨ekładów i przedstawienia teatralnego (sic!) (s. 116-117). Czytelnika polskojęzycznego moga zdezorientować zwroty „czytać pionowo” i „czytać poziomo”. Nie jestem pewien, czy dobrze rozumiem intencję autora. Wydaje mi się jednak, że w polszczyźnie Tokimasy Sekiguchiego czytać pionowo $=$ czytać $\mathrm{w}$ przekładzie na japoński. Po japońsku pisze się z góry na dól, a kolejne kolumny-wersy idą od prawej do lewej strony. Do takiej konkluzji upoważnia mnie jedno zdanie tego eseju: „Odstępuję teraz od tytułu mojego tekstu, bowiem Nishi Masahiko już nie czyta Gombrowicza pionowo po japońsku, tylko poziomo w oryginale" (s. 111). Czy ta innowacja autora Esejów nie całkiem polskich ma szansę utrwalić się w polszczyźnie? Może we frazeologii środowiskowej, wśród tych, którzy poruszają się w kręgu japonistów i sinologów? W aneksie zostało odnotowane tylko jedno przedstawienie teatralne (Iwona, księzniczka Burgunda, Tokio 1997). Przypominam sobie, że w 2004 r. oglądałem w Tokio, zresztą razem z Sekiguchim, 
Ferdydurke w inscenizacji lubelskiego Teatru Provisorium ${ }^{21}$. Rodzi się więc pytanie, jak traktować tego typu gościnne występy? Czy przedstawienie to powinno zostać odnotowane w aneksie pt. Gombrowicz, waponii?

Jak już wspomniałem, ostatni w tej części książki esej ma nieco inny charakter - ani nie dotyczy twórczości jakiegoś konkretnego autora, ani nie jest to synteza poprzedzających go szkiców, ani wreszcie nie mieści się - tak jak pozostałe eseje w szeroko pojmowanej historii literatury czy krytyce literackiej. Jest to natomiast bardzo ważny tekst programowy. Tokimasa Sekiguchi wskazuje w nim w postaci słów kluczy listę zagadnień, którymi teksty polskie mogą wzbogacić humanistykę światowa, oraz udziela ważnych wskazówek, jak to robić i jakich polonistów potrzeba poza Polska. Jego zdaniem do tekstów polskich, które mogłyby wzbogacić światową humanistykę, należą te dotyczące historii, Europy, narodu oraz tematów żydowskich. Szczegółową argumentację trudno tu przedstawić, gdyż trzeba by przepisać w całości ten bardzo skomprymowany tekst. Wymieniam więc jedynie te kwestie, które z różnych powodów przyciągnęły moją uwagę. Sekiguchi przypomina, ,że w wielu krajach świata naukę humanistyczną o Europie monopolizowali nauczyciele wykształceni w paru zaledwie narodowych filologiach, czyli angliści, romaniści, germaniści, oraz historycy ze znajomością angielskiego, francuskiego i niemieckiego" (s. 145). A przecież istnieje ogromna liczba tekstów polskich, które mogłyby być ważne do studiów nad ideą Europy, lecz nie są czytane, obecne w obiegu, gdyż nie zostały przetłumaczone. Wśród nich ważne są - zdaniem Sekiguchiego - szczególnie te, które dotyczą Polski jako przedmurza chrześcijaństwa, a następnie przedmurza Europy (s. 147).

Jaki pożytek może odnieść czytelnik niepolskojęzyczny z lektury tekstów polskich poświęconych zagadnieniom narodowym? Sekiguchi odpowiada: „kwestia idei i świadomości narodowej jest jak najbardziej uniwersalną i ciagle aktualną sprawą dla każdego człowieka na świecie. Choć rozwiązania à la polonaise problemu, literackie recepty na niego nie są wszędzie stosowalne, nowoczesne teksty polskie, jako zapiski i świadectwo, doskonale wręcz ukazują mechanizm psychiki w warunkach ekstremalnych, nakreślają możliwe granice biegunów, do jakich umysł ludzki może dochodzić" (s. 150). Niejako przy okazji dyskusji o narodzie, ale dotyczy to i innych zagadnień, autor eseju zauważa, że nie chodzi o wartość literacką tekstów. W pewnym kontekście „na przykład Ksiegi narodu i pielgraymstwa polskiego są ważniejsze niż Pan Tadeusž" (s. 150). Wychodząc nieco poza esej, możemy dodać, że nasza krajowa hierarchizacja tekstów nie obowiązuje poza rodzimym kręgiem kulturowym, a na to, co w danej kulturze i dlaczego znajdzie uznanie, poczytność i wejdzie w interakcję

${ }^{21}$ Lubelski Teatr Provisorium występowal w tokijskim Theater X w dniach 3-6 grudnia 2004 r. Nie wiem, jaki był udział Tokimasy Sekiguchiego w sprowadzeniu zespołu do Japonii. Pamiętam jednak wyraźnie, że zaangażował się w to przedsięwzięcie Hitoshi Morimoto, wtedy student polonistyki TUFS. 
z tekstami innych kultur, ostatecznie nie mamy wpływu. Dla mnie takim ekstremalnym przykładem jest popularność Jarosława Iwaszkiewicza w Chinach, szczególnie zaś opowiadania pt. Poziomka, które jest obowiązkową lekturą w chińskich szkołach $^{22}$, podczas gdy w Polsce jest to tekst szerzej nieznany, a jego autor pozostaje pisarzem niedocenionym.

Jeśli chodzi o kwestie żydowskie, to Tokimasa Sekiguchi przypomina, że świat wie o zagładzie Żydów, zna pojęcia, takie jak „Auschwitz” czy „Holocaust”, lecz nie wie niczego o dziejach Żydów przed „ostatecznym rozwiązaniem”. Tę lukę mogą i powinny wypełnić teksty polskie. Prowadzi to autora eseju do następnego problemu - braku polonistów. Brzmi to w pierwszym momencie dziwnie, lecz Sekiguchiemu chodzi o „polonistów, którzy by mogli udostępniać owe ezoteryczne teksty szerszej publiczności lokalnego społeczeństwa; polonistów o szerokim horyzoncie myślenia i odpowiednim wykształceniu humanistycznym" (s. 153). To zresztą dotyczy nie tylko problemu tekstów z zakresu problematyki żydowskiej, nawet nie tylko tych z obszarów wskazanych przez autora eseju.

Esej kończy się ważnym postulatem: „trzeba kształcić więcej polonistów i może już nie misjonarzy, ale tubylczych polonistów o szerokich horyzontach, najlepiej tej miary, co Rolf Fieguth czy Cheong Byung Kwon albo - biorąc przykład znowu z sasiedniej dziedziny - Timothy Snyder czy Norman Davies" (s. 154). Myślę, że mógłbym tę listę poszerzyć, jeśli nie czynię tego, to jedynie z obawy, by wspominając jedną postać, nie pominąc innej. Niezależnie jednak od tych obaw i nie wychodząc poza Japonię, do tej grupy mogę zaliczyć Masahiko Nishiego, o którym Sekiguchi pisał w eseju poświęconym Gombrowiczowi. Do tej grupy zaliczymy także autora książki Eseje nie całkiem polskie. Wielkie to szczęście dla kultury i literatury polskiej, że ma w Japonii takiego ambasadora. Niewattpliwie jego esej Teksty polskie w kontekstach pozapolonistycznych powinien się znaleźć wśród lektur obowiązkowych tych wszystkich, którzy zajmują się organizacją studiów polonistycznych, nauczaniem języka polskiego jako obcego oraz promocją języka i kultury polskiej poza Polska.

W drugiej części ksiażzi umieszczono tylko jeden, relatywnie długi, esej pt. Aæ̌ja nie istnieje (s. 157-199). Jest to tekst mieszczący się w nurcie badań dziś najczęściej zwanych postcolonial studies (studia postkolonialne, krytyka postkolonialna), zapoczątkowanych przez Edwarda W. Saida ksiażką Orientalizm (1978). Sam termin „studia

${ }^{22}$ O Poz̧iomce Iwaszkiewicza w Chinach mówiła prof. Wu Lan, pekińska polonistka, tłumaczka, znawczyni literatury polskiej w wykładzie otwartym pt. „Pan Tadeusz” po chińsku (KUL, Lublin, 4 kwietnia 2017 r.). Podobnie Li Yinan: „Iwaszkiewicz jest jednym z najpopularniejszych polskich pisarzy w Chinach, a jego Pożomka cieszy się szczególną popularnością, jej przekład umieszczono w różnych antologiach i zbiorach literackich. Co ciekawe, Poziomka została wpisana w Chinach do kanonu szkolnych lektur obowiązkowych, a problematyka utworu pojawiła się wśród tematów ogólnochińskiego egzaminu wstępnego na studia wyższe" (eadem, Recepcja literatury polskiej w Chinach: teoria i dzieje, „Postscriptum Polonistyczne” 2016, nr 2 (18), s. 177). 
postkolonialne" w tym tekście jednak się nie pojawia. Tokimasa Sekiguchi widzi podobieństwo swojego stanowiska do tez Saida i chyba z żalem (niepotrzebnie!) stwierdza, że podobne tezy wykładał już wcześniej, nim książka Saida zdobyła świat. Taki już los tych, którym przyszło tworzyć w językach innych niż tzw. języki światowe. Przeczytałem nieliczne prace z obszernej grupy publikacji z zakresu studiów postkolonialnych. Prawdziwie urzekło mnie kilka, oprócz Orientalizmu Saida m.in. Trubadursy imperium Ewy M. Thompson i właśnie Aæja nie istnieje Sekiguchiego. Prace powstałe w Polsce często mnie odpychaja jako importowane nowinki. W eseju Tokimasy Sekiguchiego natomiast przyciaga mnie świeżość i oryginalność spojrzenia oraz stawianie w centrum raczej konkretnych problemów niż roztrząsanie teoretycznych postaw stosowanej metodologii badawczej.

Esej Azja nie istnieje składa się z dwóch części. W pierwszej autor dowodzi, że „»Azja« jako taka nie istnieje i niepotrzebny jest termin »Azja« jako koherentna kategoria geograficzna mająca swoje odpowiednie elementy składowe rzeczywistości" (s. 157), co pokazuje różnorodność demograficzna, językowa, kulinarna, religijna wschodniej części kontynentu euroazjatyckiego, jego „bigosowatość” (termin i cudzysłów T. Sekiguchiego, s. 163). W drugiej z kolei obserwujemy wraz z jego autorem „historię obrastania geograficznego terminu »Azja« w negatywne konotacje” (s. 191). Pokazuje to autor „na przykładzie słów »Azja«i »azjatyckość« - tak głęboko zakorzenionych w językach europejskich, mających silnie rozbudowaną wręcz teorię stosowania oraz system asocjacji - że najczęściej to sam język dyktuje nam sposoby widzenia zjawisk i że same pojęcia nami operują, a nie odwrotnie, pozbawiając nas też częściowo woli i możliwości empirycznego poznawania świata” (s. 198). Ten cel udało się autorowi w pełni zrealizować.

W tym miejscu chciałbym wrócić do części pierwszej recenzowanego zbioru. Jak już wspomniano, zamieścił tam autor szkic pt. Z Panem Wołodyjowskim do Kamieńca - inne spojrzenie na Trylogię Henryka Sienkiewricza (s. 77-98). Najważniejsza jego częścią jest bowiem postkolonialna analiza Wschodu i Azji w Trylogii. Badacza interesuja - jak pisze - Henryka Sienkiewicza „teksty same w sobie, ich siła językotwórcza, znakotwórcza i ich efekty" (s. 87). Proste zestawienie cytatów z Pana Wotodyjowskiego idealnie dowodzi, że „niezależne od świadomości i wiedzy posługującego się językiem polskim, Pan Wołodyjonski stanowił bardzo ważne źródło, które zasilało korpus polszczyzny dotyczący słów i pojęć »Wschód« i »Azja«" (s. 97). Pomijam w tym zestawieniu inny ważny problem w tym eseju - hermetyczne zamknięcie literatury polskiej po romantyzmie.

Cześć trzecia Esejów nie catkiem polskich ma nieco inny charakter. Opublikowane tu eseje są bardziej osobiste. Niektóre odbieram także jako teksty na poły literackie. W pierwszym - Daleko do Ameryki - zJaponii (s. 203-208) - autor książki pisze o swojej drodze do Ameryki (dosłownie w 1980 r. i metaforycznie). Moją uwage zwróciły dwie kwestie. Pierwsza to polityka USA wobec pokonanej w 1945 r. Japonii i naiwna wiara „, »demokratycznąu i »liberalnąu politykę Amerykanów” (s. 205). 
Czytam ten tekst w kontekście naszej polskiej naiwnej wiary w politykę UE (raczej lewica), USA (raczej prawica) lub obu skrzydeł politycznego spectrum wiary w ex occidente lux. Druga sprawa to rezultat polityki amerykańskiej. Jak pisze Sekiguchi o zamerykanizowaniu Japonii, „,w dziedzinie konsumpcji - być może [to się udało], ale nie w głębszej warstwie. Mimo różnego rodzaju »reform« amerykański duch nie przyjął się na gruncie japońskim ani w polityce, ani w biznesie, ani w edukacji” (s. 207). Czy tego samego nie można powiedzieć o sowietyzacji Polski po 1945 r.? Czy ten sam mechanizm (nie) działa obecnie? W dziejach kultury - zdaje się - łatwo wskazać sytuacje, gdy kultura narzucana z zewnątrz przyjmuje się bardzo powoli, ulegając przy tym przekształceniom, tak że nawet po stuleciach w nowej kulturze można dostrzec ślady starego porządku semiotycznego, czego przykładem są choćby przeżytki pogaństwa w chrześcijaństwie.

W bardzo interesującej książce z 1883 r. Slavic and Latin: Ilchester Lectures on Comparative Lexicography, delivered at the Taylor Institution, Oxford (London 1883) nieznany mi bliżej niemiecki filolog Carl Abel, opisując różnice między przodkami dzisiejszych Ukraińców a przodkami dzisiejszych Rosjan (w jego terminologii odpowiednio „Ruś Słowiańska” i „Ruś Fino-Tatarska”) napisał: „The shell is the same, the kernel varies" - w języku i kulturze Rosjan widać wyraźnie ugrofińskie i mongolskie fundamenty. Gdy więc w następnym szkicu pt. Cžas po japońsku (s. 209-222) Sekiguchi sugeruje, że „stara świadomość czasu może przetrwała w głębszych warstwach naszej psychiki i kultury niczym podświadomość zbiorowa" (s. 221), to chyba w trwałości kultury pokłada jakąśs nadzieję na jej ocalenie.

Tematem tego szkicu jest japońska konceptualizacja czasu. Autor analizuje w nim cztery aspekty czasu po japońsku: silny tradycjonalizm filozoficzny i poczucie schyłkowości czasów, niezwykłą wrażliwość na przemijalność czasu, cykliczność lub „wahadłowość” czasu i wreszcie przewagę zasady przestrzennej nad zasadą czasową (s. 209-210). To tekst dla wszystkich, którzy interesują się różnicami w konceptualizacji rzeczywistości między językami, kulturami, narodami. Interesujący punkt wyjścia dla dalszych analiz. Konkluzje autora nie sa jednak wesołe. Japonię i Japończyków sto lat temu opanowała epidemia - kult postępu i obsesja na punkcie rozwoju (s. 221). „Scjentyzm zaczął miażdżyć tradycjonalizm, utylitaryzm odpychał estetyzm. A czas został wyprostowany i mknie do przodu z szybkościa ponad 200 km na godzinę" (s. 222). W tej rzeczywistości, w tym chaosie panującym w Japonii nie sposób dalej żyć. Czy autor szkicu zgodzi się ze stanowiskiem, że on sam reprezentuje tu ów, opisywany w szkicu, tradycjonalizm historiozoficzny i poczucie schyłkowości dziejów?

Z właściwości czasu po japońsku moją uwagę przykuła zasada dominacji przestrzeni nad czasem - „wydaje mi się, że starożytni Japończycy myśleli bardziej w sposób przestrzenny aniżeli w sposób czasowy" (s. 220). Bez tej zasady nie można by zrozumieć i zacytowanego wyżej zdania o czasie, który „mknie do przodu z szybkością ponad $200 \mathrm{~km}$ na godzinę". Homologiczność czasu i przestrzeni znają 
również inne kultury, także polska. Jak pisze Anna Pajdzińska, „Analiza polskich wyrażeń nie pozostawia wattpliwości, że nasze pojmowanie czasu jest w znacznej mierze (jeśli nie w pełni) metaforyczne. Wiele metafor pozwala uchwycić sens pojęcia w terminach przestrzennych, np. odcinek czasu, granice czasowe, dtugi czas, krótki czas, kawat crasu, szmat crasu, odlegtość w czasie, w odsteppach czasu, bliska pržesżość, daleka pryysztosíc, wolny czas, zajety czas, coś zajeto czas"23. Ujmowanie czasu w kategoriach przestrzennych $\mathrm{w}$ języku polskim i japońskim, ponieważ nie może być wynikiem wzajemnej infiltracji naszych języków i kultur, musi wynikać z tożsamości poznawczej ludzi jako gatunku. W głębi, pod maską języka i kultury, jesteśmy takimi samymi ludźmi. Na marginesie eseju Czas po japońsku można powiedzieć, że często nawet ludzie wykształceni przeceniają różnice między kulturami, nie dostrzegając tego, co w nich ogólnoludzkie.

O eseju Forsycja i czeremcha (s. 221-235) wspomniałem już okazjonalnie, z powodu Miłosza, wyżej. Motywem przewodnim jest tu refleksja nad istotą nauczania i uczenia się języków obcych. Na własnym przykładzie Tokimasa Sekiguchi przedstawia jeden $\mathrm{z}$ ważnych motywów uczenia się języka obcego - „chęć opisywania świata wedtug wtasnej jego wizjil” (s. 223, kursywa T.S.), pragnienie, aby wyrażać świat w języku obcym. Szukam w tym tekście odpowiedzi na pytanie, co sprawiło, że młody Sekiguchi chciał nie tylko po japońsku mówić o forsycji, magnolii, czeremsze, podczas gdy jego obecni studenci w Tokio nie interesują się, „co teraz kwitnie czy też pachnie; co taką miłą woń roztacza, nazywa się wawrzynek wilczełyko; nie obchodzi ich wcale to, że aleja, przy której stoi uniwersytet, jest pięknie wysadzana dereniem świdwa, a o tym wszystkim przecież po japońsku rozmawiamy!” (s. 226). Inaczej mówiąc, interesuje mnie, jak wyjść w uczeniu się języka obcego poza poziom codziennej konwersacji, poza rozmowy o pogodzie, o cenach i zakupach, polityce etc. Myślę, że na to pytanie mogę odpowiedzieć albo anegdotycznie, albo ewangelicznie.

Przed laty, gdy jeszcze obowiązywały egzaminy wstępne na studia w Polsce, wielokrotnie egzaminowałem z języka polskiego ( $=$ z literatury polskiej z zakresu szkoły średniej) kandydatów na filologię germańską w Katolickim Uniwersytecie Lubelskim. I nie raz zdarzało się, że kandydat $(\mathrm{ka})$ z dobrą znajomością podstaw języka niemieckiego nie dawał(a) sobie rady z egzaminem z polskiego. Byłem skłonny przymknąć oko na nieznajomość literatury polskiej, ale prof. Jerzy Jeszke, znany lubelski germanista, sprowadzał mnie wtedy na ziemię, mówiąc: jak kandydat $(k a)$ nie ma nic do powiedzenia w języku polskim, to o czym będzie rozmawiać po niemiecku.

Odwołując się do frazeologii rodem z Ewangelii, mógłbym o tej samej sytuacji powiedzieć: „obfitością serca usta mówią” (Mt 12, 33-37). Można znać wiele języków, lecz - jak w znanej anegdocie o Michale Korybucie Wiśniowieckim - w żadnym

23 A. Pajdzińska, Drieci Heraklita (poeci o çasie) [w:] Kreowanie swiata w tekstach, red. A.M. Lewicki, R. Tokarski, Lublin 1995, s. 89-103. 
nie mieć nic do powiedzenia ${ }^{24}$. Czyż bowiem może zaistnieć potrzeba wyrażenia się w języku obcym, który dopiero poznajemy, jeśli nie czujemy jej w swoim języku ojczystym? Czytając Eseje nie całkiem polskie Tokimasy Sekiguchiego, czujemy wyraźnie (jak dowieść tych odczuć?), że ich autor ma wiele do powiedzenia, że zgłębił ogromną liczbę tekstów najpierw japońskich, potem francuskich, angielskich i polskich „czytanych pionowo” i wreszcie tych samych „czytanych poziomo”, w oryginale. Forsycja, magnolia i czeremcha „stały się spoiwem dwu światów, miejscem, poprzez które zaczęło wreszcie przepływać SŁOWO” (s. 226). Spotkały się jednak nie tylko dwa światy fizyczne. W interakcję weszły także przestrzenie tekstów. W tym początkowym okresie nauki języka autor eseju zauważa bliskość poezji Harasymowicza do haiku, by wkrótce odkryć, jak jest pozorna (s. 233).

W eseju Mój pierws zy Pekin - refleksje podróżnego z dygresjami (s. 237-252) Sekiguchi san tłumaczy, co go oszołomiło podczas pierwszego pobytu w Pekinie w 2010 r. Tytuł dobrze oddaje zawartość tekstu. Pekin jeszcze przede mna. Znam jednak południowo-wschodnią Azję wystarczająco, by nie tyle zgodzić się z tezą, że obecnie „Pekin faktycznie stał się stolicą świata” (s. 237), ile dopowiedzieć, że wiele znaków na ziemi ${ }^{25}$ wskazuje, iż w Europie i w USA nie zauważono przesunięcia się centrum świata już jakiś czas temu w tamten region.

Tokimasa Sekiguchi jest bardzo uważnym czytelnikiem tekstów „,polskojęzycznych”, gdyż czyta je - jeśli mogę tak powiedzieć - sam jeden, lecz w wielu osobach - jako badacz i znawca kultury (w tym literatury), jako tłumacz, wreszcie jako wnikliwy i subtelny czytelnik oraz miłośnik najróżniejszych tekstów literackich. To wieloosobowe czytanie widać w wielu omówionych wcześniej szkicach. Natomiast tylko jeden z nich, przedostatni w całej książce, jest poświęcony zagadnieniom translatorskim wprost - Refleksje ttumacza nowej Korespondencji Fryderyka Chopina (2009), s. 252-266 ${ }^{26}$. Jednak i tu tłumacza zwycięża badacz, który wskazuje ważne problemy badawcze chopinologii chyba nie tylko polskiej, a najważniejsze okazują się refleksje o charakterze ogólnym - nie ujmując nic technicznej stronie analizy zagadnień edytorskich i translatorskich starego i nowego wydania listów Chopina. Lektura nowego warszawskiego wydania Korespondencji Fryderyka Chopina pozwala eseiście zwrócić uwagę m.in. na kontakty wielkiego kompozytora z Żydami oraz znajomość ich muzyki. Jak czytamy w eseju: „Na podstawie listów można stwierdzić, że młody Chopin poświęcał tyle samo uwagi polskiej muzyce ludowej, co muzyce żydowskiej, czerpiąc przy tym z nich obu ogromnie dużo" (s. 262). Moge

24 Por. A. Chwalba, Obyczaje w Polsce: od średnioniecza do czasón wspótczesnych, Warszawa 2006, s. 124.

25 Patrząc na chińskie osiagnięcia w podboju kosmosu, można by napisać „,wiele znaków na niebie i ziemi".

26 Mowa o przekładzie nowego wydania listów Chopina z lat 1816-1831 (F. Chopin, Korespondencja Fryderyka Chopina, oprac. Z. Helman, Z. Skowron, H. Wróblewska-Straus, Warszawa 2009, zbiorowy przekład japoński ukazał się w 2011 r.; zob. przyp. 10). 
tylko zgodzić się z autorem eseju, że „Zainteresowanie Chopina muzyką żydowską i potencjalne jej wpływy na kształtowanie się jego sztuki to rzadko poruszany temat” (s. 262). Podobnie jest z teza, że Chopin „daleko odbiegał od wzorca ówczesnego romantyka", a jego fascynacja Mickiewiczem to tylko legenda (s. 266). Kto nie przeczyta osobiście listów Chopina w nowym wydaniu, musi się z nim zgodzić. Kto przeczyta, zgodzi się tym bardziej.

Trzecią część książki i cały tom kończy krótki esej pt. Mój Kantor (s. 267-271). Eseista stawia tu obok siebie Umarła klase Kantora i dwa japońskie przedstawienia (niewymieniony z tytułu spektakl zmarłego w 1986 r. reżysera-tancerza Tatsumi Hijikata i przedstawienie sztuki Nō pt. Kakitsubata). Wszystkie one były dla niego przeżyciem teatralnym, „po którym człowiek się czuje, ba, staje się innym” (s. 268). Wszystkie trzy sztuki łączy ich aliterackość (s. 268). „To, co się tworzyło na deskach, nie dążyło do tego, by znaczyć, wręcz przeciwnie, jak tylko cień znaczenia się rodził, rozpraszało go" (s. 268).

Większość czytelników, nie tylko starszych i wychowanych tradycyjnie, odnotuje konsekwentne użycie w książce przymiotnika ,polskojęzyczny” (polskojęzyczny tekst, literatura polskojęzyczna etc.). Przymiotnik ten upowszechnił się w polszczyźnie stosunkowo niedawno, w ostatnich dziesięcioleciach XX w., w znaczeniu 'mówiący językiem polskim, związany z językiem polskim', np. serwis polskojęzycz$n y^{27}$. Równocześnie „przymiotnik polskojęzyczny z wyrazu o znaczeniu 'polski, nasz' przekształcił się w etykietę piętnującą (...) inność, która - jako stanowiąca zagrożenie - uznawana jest za obcość" ${ }^{28}$. Świadomość językowa podpowiada mi, że w dyskursie publicznym to drugie znaczenie powoli zaczyna dominować. W sposobie użycia przymiotnika „polskojęzyczny” w książce Sekiguchiego nie widzę nic więcej nad dążenie do precyzji znaczeniowej.

Wiem równocześnie, że pytanie, czy istnieje literatura - szerzej kultura - polskojęzyczna, może się wydać wielu moim rodakom absurdalne. Co jednak zrobić z takimi fenomenami, jak np. książka Tatiany Szkapienko Transseksmisja (Lublin 2007) czy książki Dmitrija Strelnikoffa Ruski miesiac (Warszawa 2008), Fajnie być samcem (Warszawa 2011). Ich autorami są Rosjanie (?), ale powstały w języku polskim, funkcjonują w Polsce. Czy to jest (popularna) polskojęzyczna literatura rosyjska? Czy już literatura polska ${ }^{29}$ ? Kształcącym dla mnie przykładem jest twórczość Iwana Franki. Znaczna jej część, w tym także niektóre powieści (Lelum Polelum, Dla domowego ogniska), powstały w języku polskim. Czy to literatura polska? Czy polskojęzyczna litera-

27 Po raz pierwszy odnotowany w suplemencie do Stownika jezylka polskiego Mieczysława Szymczaka (1992). Podaję za: W. Chlebda, Kiedy swój staje się obcym, „Etnolingwistyka” 2007, t. 19, s. 95.

28 Ibidem, s. 96.

29 W katalogu Biblioteki Narodowej Szkapienko zakwalifikowano do gatunku powieść rosyjska - 21 w., a Ruski miesiac Strelnikoffa do dwu gatunków: powieść polska - 21 w., powieść rosyjska 21 w. Fajnie być samcem brak w Bibliotece Narodowej. Stan z dnia 23 sierpnia 2017 r. 
tura ukraińska30? Myślę, że i twórczość „polskojęzyczna” niektórych pisarzy żydowskich też może stwarzać takie problemy. Zdaję sobie sprawę z istnienia tego typu trudności klasyfikacyjnych, nie wiem jednak, czy najnowszy uzus językowy pozwala mi w takich sytuacjach używać przymiotnika „polskojęzyczny”. Niepolskojęzyczny autor Esejón nie catkiem polskich nie mógł chyba pisać inaczej? Jego konsekwencja prowokuje do myślenia o tej kwestii. Może się to przydać w opisie zjawisk zarówno w najnowszej literaturze i kulturze, jak i w ich interpretacji w przeszłości.

Myślę, że wybrane Eseje nie całkiem polskie będą czy też powinni czytać badacze twórczości Herberta, Szymborskiej, Miłosza, Sienkiewicza, Gombrowicza, Prusa. Mogą one również zainteresować badaczy i miłośników innych pisarzy, ważnych postaci zarówno polskiego, jak i japońskiego życia literackiego i kulturalnego, np. Pawlikowskiej-Jasnorzewskiej (s. 32), Harasymowicza (s. 233-234), ale też wielu innych (więcej nazwisk w indeksie na s. 277-283). We fragmentach książka zainteresuje także badaczy interesujących się krytyką postkolonialną. Sięgna po nią zainteresowani obecnością języka i kultury polskiej w świecie, szczególnie ci zainteresowani Azją Wschodnia. Nie w tym jednak upatruję jej wartość. Łącząc w jednej książce te dość różne teksty, ich autor osiagnął coś, co w ekonomii nazywa się synergia - powstała nowa jakość. Myślę, że Tokimasa Sekiguchi nie chciał konkurować na różnych polach działalności badawczej z uczonymi w Polsce, choć osobiście jestem przekonany, że może! Najważniejsza jest bowiem w lekturze tej książki „zmiana perspektywy" 31 Tokimasa Sekiguchi ma nam coś ważnego do powiedzenia wszędzie tam, gdzie patrzy na sprawy polskie z zewnątrz. Dlatego polecam Eseje nie catkiem polskie wszystkim, którym los kultury polskiej nie jest obojętny.

\section{SUMMARY}

\section{LIGHT FROM THE EAST. ON "ESEJE NIE CAŁKIEM POLSKIE” [NOT ENTIRELY POLISH ESSAYS] BY TOKIMASA SEKIGUCHI}

The article discusses thoroughly the book "Eseje nie całkiem polskie" [Not Entirely Polish Essays] by Tokimasa Sekiguchi, a professor at Tokyo University of Foreign Studies. In his book, the author focuses on the issue of transculturality. The book consists of three parts. The first is mostly about historical and literary contexts. Sekiguchi writes about different

30 Mówiłem o tym w referacie pt. Iwan Franko polskojezyczny. Kilka uwag z powodu powieści „Dla domowego ogniska”, wygłoszonym na konferencji Dialog dwóch kultur, która odbyła się w Krzemieńcu we wrześniu $2016 \mathrm{r}$.

31 Świadomie nawiązuję tu do tytułu książki Zuzanny Topolińskiej - Zmiana perspek.tyny. Gaweda nie tylko jezylkoznawcza (Kraków 2015). Topolińska, językoznawca, badaczka języka macedońskiego, podnosi w niej kwestię, jak z perspektywy południa świata słowiańskiego inaczej wyglądaja sprawy polskie. Moja recenzja tej książki ukaże się wkrótce w „Roczniku Slawistycznym”. 
aspects of works by Herbert, Miłosz and Szymborska. The second part is actually one essay entitled "Asia Does Not Exist". Two issues are worthy of attention in this part. On the one hand, we can see Sekiguchi as a precursor of Postcolonial Studies; on the other, we see quite an original take on problems known from such classic works like "Orientalism" by E.W. Said. The third part of Sekiguchi's book has a slightly different character. The essays here are more personal, and some of them could be read as a semi-literary works. A very thorough study of the essays leads the author of the article to the conclusion that the pivotal aspect of Sekiguchi's work is a change of perspective: while Sekiguchi looks at Poland's internal affairs from the outside, he has a lot to say to us, Poles and to other nations as well. 